Article

\title{
Branched Sulfonimide-Based Proton Exchange Polymer Membranes from Poly(Phenylenebenzopheneone)s for Fuel Cell Applications
}

\author{
Sabuj Chandra Sutradhar ${ }^{1,+}{ }^{+}$, Sujin Yoon ${ }^{1,+}$, Taewook Ryu ${ }^{1}$, Lei Jin ${ }^{1}$, Wei Zhang ${ }^{1}{ }^{\circledR}$, Whangi Kim ${ }^{1}(\mathbb{D}$ \\ and Hohyoun Jang ${ }^{2, *(D)}$ \\ 1 Department of Applied Chemistry, Konkuk University, Chungju 27478, Korea; \\ sabujchandra@gmail.com (S.C.S.); ysj920126@naver.com (S.Y.); gundam0924@naver.com (T.R.); \\ jinlei8761@naver.com (L.J.); arno_zw@hotmail.com (W.Z.); wgkim@kku.ac.kr (W.K.) \\ 2 Department of Liberal Art, Konkuk University, Chungju 27478, Korea \\ * Correspondence: 200417450@kku.ac.kr; +82-43-840-4764 (ext. 410) \\ + These authors contributed equally to this work.
}

check for

updates

Citation: Sutradhar, S.C.; Yoon, S.; Ryu, T.; Jin, L.; Zhang, W.; Kim, W.; Jang, H. Branched Sulfonimide-Based Proton Exchange Polymer

Membranes from

Poly(Phenylenebenzopheneone)s for Fuel Cell Applications. Membranes 2021, 11, 168. https://doi.org/ 10.3390/membranes11030168

Academic Editor: Metin Uz

Received: 1 February 2021

Accepted: 23 February 2021

Published: 27 February 2021

Publisher's Note: MDPI stays neutral with regard to jurisdictional claims in published maps and institutional affiliations.

Copyright: (c) 2021 by the authors. Licensee MDPI, Basel, Switzerland. This article is an open access article distributed under the terms and conditions of the Creative Commons Attribution (CC BY) license (https:/ / creativecommons.org/licenses/by/ $4.0 /)$.

\begin{abstract}
Improved proton conductivity and high durability are now a high concern for proton exchange membranes (PEMs). Therefore, highly proton conductive PEMs have been synthesized from branched sulfonimide-based poly(phenylenebenzophenone) (SI-branched PPBP) with excellent thermal and chemical stability. The branched polyphenylene-based carbon-carbon backbones of the SI-branched PPBP membranes were attained from the 1,4-dichloro-2,5-diphenylenebenzophenone (PBP) monomer using 1,3,5-trichlorobenzene as a branching agent $(0.1 \%)$ via the Ni-Zn catalyzed C-C coupling reaction. The as-synthesized SI-branched PPBP membranes showed 1.00 1.86 meq./g ion exchange capacity (IEC) with unique dimensional stability. The sulfonimide groups of the SIbranched PPBP membranes had improved proton conductivity $(75.9-121.88 \mathrm{mS} / \mathrm{cm})$ compared to Nafion $117(84.74 \mathrm{mS} / \mathrm{cm})$. Oxidation stability by thermogravimetric analysis (TGA) and Fenton's test study confirmed the significant properties of the SI-branched PPBP membranes. Additionally, a very distinct microphase separation between the hydrophobic and hydrophilic moieties was observed using atomic force microscopic (AFM) analysis. The properties of the synthesized SI-branched PPBP membranes demonstrate their viability as an alternative PEM material.
\end{abstract}

Keywords: proton exchange membrane; sulfonimide; nickel catalyzed polymerization; ion exchange capacity; dimensional stability; proton conductivity

\section{Introduction}

Proton exchange membrane fuel cells (PEMFCs) have become the most popular renewable energy resource because of their high efficiency, high energy density, quiet operation, and environmental friendliness [1-5]. Proton exchange membranes (PEMs) are the key component of these fuel cells and are primarily based on a perfluorosulfonic acid called Nafion. Despite Nafion's high proton conductivity and good chemical and oxidative stability, its low-temperature operation, high manufacturing cost, harsh chemical modifications and high fuel permeability have stimulated researchers to find alternatives to Nafion [6-10]. Therefore, aromatic hydrocarbon-based polymer membranes, such as sulfonated poly(ether ether ketone)s (PEEK) [3,11-14], polysulfones (PSF) [15-17] and poly(arylene ether)s (PAE) [18-21] have been studied for over a decade as alternative membranes to Nafion. A class of composite polymer electrolyte membranes containing SPSU-LDH [22], PBI-SiO 2 [23], and SGO-SPAES [24] have shown interconnecting proton transport channels, a phase-separated morphology and enhanced thermo-mechanical resistance, water retention capacity and high dimensional stability. However, the lack of considerable thermal and oxidative stability made the use of these polymer membranes as 
proton exchange membranes inappropriate. Meanwhile, to improve the oxidative stability of these linear polymers, researchers have suggested using cross-linked polymers for fuel cell applications [25-27]. However, the insolubility of these cross-linked membranes in common organic solvents has impeded their ability to used as PEMs in commercial processes. Researchers have also suggested that branching polymer membranes, which have good solubility in organic solvents, have an excellent potential to be used as PEMs materials. However, very few branched PEMs have been studied compared to cross-linked PEMs [4,28-36]. Hay et al. [4] has reported branched polymers containing sulfonic acid as end groups whereas Ueda et al. [34] has studied sulfonated block copolymer with sidearms. Park et al. [37]. and Wang et al. [29,38] have reported sulfonated block copolymers containing $0.4 \%$ and $2-4 \%$ branching agents for getting high molecular weight. Combshaped sulfonated polymers [39-44] have also been reported to have highly branched backbones with flexible side chains. These comb-shaped sulfonated polymers show good mechanical properties. Nevertheless, most of these branched polymer membranes are susceptible to nucleophile attack as the polymer backbones are based on ether linkages, and acid functional groups are attached to the main chain $[17,45]$. Conversely, polyphenylene membranes exhibit excellent durability, thermo-oxidative stability and good solubility in organic solvents [46-51]. Additionally, sulfonimide acid functional groups have super gasphase acidity [49]. The pendant side-chain type sulfonimide groups provide very distinct micro-phase morphology. Moreover, the fluorine atom of the sulfonimide acid moiety enhances the chemical stability of the polymer membranes by protecting the polymer backbones from free radical attacks during fuel cell operation.

Therefore, in this study we have synthesized polyphenylene membranes without any ether linkages using Ni-Zn catalyzed C-C coupling polymerization in order to overcome the thermal, chemical stability and proton conductivity obstacles associated with polymer membranes. The as-synthesized polyphenylenes backbones containing pendant benzoyl groups are believed to exhibit excellent thermal and chemical stability. Furthermore, super gas-phase acidic fluoro-sulfonimide acid functional groups have been introduced in the polymer side chains to improve proton conductivity, chemical stability, and structural flexibility.

\section{Materials and Methods}

\subsection{Materials}

2,5-dichloro-p-xylene, potassium permanganate, benzene, pyridine, nickel bromide, thionyl chloride, triphenylphosphine and zinc powder were purchased from TCI (Tokyo, Japan), Sigma-Aldrich (St. Louis, MO, USA) and Alfa Aesar (Ward Hill, MA, USA). Chlorosulfonyl isocyanate was supplied by Chumbuk (Korea). Chlorosulfuric acid, formic acid, and antimony trifluoride, respectively, were purchased from Junsei (Tokyo, Japan), Daejung Chemicals (Busan, Korea), and Alfa Aesar. Commercial solvents such as dimethylacetamide (DMAc), dimethyl sulfoxide (DMSO), dichloromethane (DMC), chloroform, methanol, ethanol and acetone were purchased from Sigma-Aldrich and used without further purification.

\subsection{Synthesis of Branched Poly(phenylenebenzophenone) (PPBP)}

Preparation of the reagents and catalysts was carried out in a glove box under an $\mathrm{N}_{2}$ condition. $\mathrm{NiBr}_{2}(0.174 \mathrm{~g}, 0.79 \mathrm{mmol}), \mathrm{Zn}$ powder $(3.03 \mathrm{~g}, 48.7 \mathrm{mmol})$ and triphenylphosphine $(1.67 \mathrm{~g}, 6.4 \mathrm{mmol})$ were put into a three-neck flask. Additionally, 1,4-dichloro-2,5diphenylenebenzophenone (PBP) $(2.0 \mathrm{~g}, 7.9 \mathrm{mmol})$ and 1,3,5-trichlorobenzene $(0.002 \mathrm{~g}$, $0.1 \%$ of PBP) were put into a one-neck flask. To begin the reaction, DMAc (3-5 mL) was added into the catalytic flask by a syringe and fitted with a mechanical stirrer under a flowing nitrogen system. It was stirred gently at $80{ }^{\circ} \mathrm{C}$ until it turned blood-red. Thereafter, the PBP monomer was dissolved into DMAc solvent and added into the catalytic flask through a syringe. The resultant mixture was stirred at $100{ }^{\circ} \mathrm{C}$ until it became a viscous, jelly-like, mixture. The viscous mixture was diluted with 8-10 mL DMAc and cooled to 
room temperature before precipitation. Then, the solution was poured while stirring into distilled water containing $30 \% \mathrm{HCl}$. When solids formed, they were collected through filtration and washed first with distilled water and then with acetone. Finally, the polymer (PPBP) was dried for $12 \mathrm{~h}$ in a vacuum oven at $60^{\circ} \mathrm{C}$.

\subsection{Sulfonation of the Branched Polymer (S-Branched PPBP)}

PPBP branched polymers $(1.5 \mathrm{~g})$ were dissolved in dichloromethane $(10 \mathrm{~mL})$ at $0{ }^{\circ} \mathrm{C}$ before slowly being added to concentrated chlorosulfuric acid $(3.18 \mathrm{~mL}, 47.8 \mathrm{mmol})$ and stirred for $6 \mathrm{~h}$ at $80^{\circ} \mathrm{C}$. The black-colored solution was then poured into distilled ice water and washed to remove residual acid. Finally, the solid polymer was rinsed with distilled water on a filter and dried at $60{ }^{\circ} \mathrm{C}$ for $24 \mathrm{~h}$.

\subsection{Conversion into Sulfonimide form of the Sulfonated Branched Polymers (SI-Branched PPBP)}

Initially, S-branched PPBP (1.0 g) was dispersed in $10 \mathrm{~mL}$ tetrachloroethane (TCE) and thionyl chloride $(20 \mathrm{~mL})$. Then, the mixture was refluxed at $75{ }^{\circ} \mathrm{C}$ for $24 \mathrm{~h}$ by adding a few drops of DMF. The resultant mixture was evaporated to obtain a paste-type residue. After dissolving again in dichloromethane $(30 \mathrm{~mL})$, fluoro-sulfonimide $(0.8 \mathrm{~g}, 8 \mathrm{mmol})$ was added slowly by a syringe at $0{ }^{\circ} \mathrm{C}$. The resultant mixture was stirred at room temperature until the solution color turned a deep orange. Finally, the mixture was carefully poured into a mixture of methanol and distilled water (5:5) to collect the sulfonimide grafted branched PPBP polymers (SI-branched PPBP) and dried at $60^{\circ} \mathrm{C}$.

\subsection{Characterizations and Measurement of Membranes Properties}

Membranes with a thickness of $25 \mu \mathrm{m}$ were made by dissolving 3\% $w / v$ SI-branched PPBP polymers in the DMAc solvent and exposing them overnight under an IR lamp on a glass plate. Typically, a RheoSense hts-VROC ${ }^{\mathrm{TM}}$ viscometer was used to measure the viscosity of the SI-PPBP polymers. The structural properties of the synthesized DCBP monomer and SI-PPBP polymers were studied using JEOL $(400 \mathrm{YH})$ for ${ }^{1} \mathrm{H},{ }^{19} \mathrm{~F}-\mathrm{NMR}$ and FT-IR spectra with Nicolet iS5 FT-IR Spectrometry (Serial no. ASB1100426). The constant weighted polymer membranes were immersed into distilled water for $24 \mathrm{~h}$ at $80^{\circ} \mathrm{C}$ and measured water uptake was as follows:

$$
\text { Water uptake, WU }(\%)=\left\{\left(\mathrm{W}_{\text {wet }}-\mathrm{W}_{\text {dry }}\right) / \mathrm{W}_{\mathrm{dry}}\right\} \times 100 \%
$$

where $\mathrm{W}_{\mathrm{dry}}$ and $\mathrm{W}_{\text {wet }}$ correspond to the weight of the membranes in dried and wet conditions, respectively.

Next, the SI-branched PPBP membranes were stirred into a $1 \mathrm{~N} \mathrm{NaCl}$ solution for $24 \mathrm{~h}$ at $80{ }^{\circ} \mathrm{C}$ to exchange the $\mathrm{H}^{+}$ions with $\mathrm{Na}^{+}$. Subsequently, the exchanged $\mathrm{H}^{+}$was evaluated by titration with $0.01 \mathrm{~N} \mathrm{NaOH}$ solution to measure the ion exchange capacity (IEC) as follows:

$$
\operatorname{IEC}(\text { meq. } / \mathrm{g})=\left(\mathrm{V}_{\mathrm{NaOH}} \times \mathrm{M}_{\mathrm{NaOH}}\right) / \mathrm{W}_{\mathrm{dry}} \text { membrane }
$$

where $\mathrm{V}_{\mathrm{NaOH}}, \mathrm{M}_{\mathrm{NaOH}}$ and $\mathrm{W}_{\text {dry }}$ correspond to the volume, molarity of the $\mathrm{NaOH}$, and weight of the membrane, respectively.

Consequently, other membrane properties, i.e., hydration number $(\lambda)$ and dimensional changes, were also evaluated as follows:

$$
\begin{gathered}
\Lambda=(10 \times \mathrm{WU} \%) /(\mathrm{IEC} \times 18) \\
\Delta \mathrm{l}(\%)=\left\{\left(1_{\text {wet }}-\mathrm{l}_{\text {dry }}\right) / \mathrm{l}_{\text {dry }}\right\} \times 100 \\
\Delta \mathrm{t}(\%)=\left\{\left(\mathrm{t}_{\mathrm{we}} \mathrm{t}-\mathrm{t}_{\text {dry }}\right) / \mathrm{t}_{\text {dry }}\right\} \times 100
\end{gathered}
$$

where, $\lambda, 1$ and $t$ represent the hydration number, length and thickness of the membranes, respectively. 
The through-plane conductivity of the SI-PPBP membranes was conducted using the MTS 740 membrane test system (Scribner Associates Inc., Southern Pines, NC, USA) with a Newton 4th Ltd. (N4L) impedance analysis interface (PSM 1735). Constant alternating current was applied through both electrodes with the membranes in the middle. A specific humidity (30-90\%) and temperature $\left(30-90{ }^{\circ} \mathrm{C}\right)$ was maintained during the operation. The conductivity of the membranes was evaluated following the equation:

$$
\sigma=\left[\mathrm{L} /\left(\mathrm{R}_{\mathrm{mem}} \times \mathrm{A}\right)\right]
$$

where $\mathrm{L}, \mathrm{A}$ and $\mathrm{R}_{\text {mem }}$ denote the thickness, electrode area, and corresponding resistance of the membranes, respectively.

The thermal property of the SI-PPBP polymer membranes was investigated with a TGA-N 1000 analyzer (Scinco, Chicago, IL, USA) at $30-800^{\circ} \mathrm{C}$ with a scan rate of $20^{\circ} \mathrm{C} / \mathrm{min}$ under air conditions.

Additionally, the chemical stability of the membranes was evaluated by heating the membranes into Fenton's reagent $\left(3 \mathrm{ppm} \mathrm{Fe}{ }^{2+}, 3 \% \mathrm{H}_{2} \mathrm{O}_{2}\right)$ at $80{ }^{\circ} \mathrm{C}$ and recording the chemical degradation by measuring the weight of the membranes at $1 \mathrm{~h}$ time intervals for $9 \mathrm{~h}$.

The hydrophilic and hydrophobic phase separation of the membrane was assessed using trapping mode atomic force microscopy (AFM) with a Nanoscope (R) IIIA and microfabricated cantilevers with an amplitude setpoint of $0.7785 \mathrm{~V}$.

Membrane electrode assemblies (MEAs) with an active area of $25 \mathrm{~cm}^{2}$ were prepared using a decal method based on a catalyst coated membrane (CCM). A $20 \mathrm{wt} \%$ wet-proofed Toray carbon paper (TGPH-060, Toray Inc.) of $190 \mathrm{~mm}$ thickness was employed as a gas diffusion layer (GDL) for the anode and cathode sides. Carbon-supported Pt (Hispec 13100, Johnson Matthey Inc.) was used as a catalyst for both anode and cathode and the loading of the catalyst layer was $0.29 \mathrm{mg} \mathrm{Pt} / \mathrm{cm}^{2}$. Immediately afterward, the catalyst layer was transferred onto the membrane at $120{ }^{\circ} \mathrm{C}$ and $10 \mathrm{MPa}$ for $5 \mathrm{~min}$ by decal method to make the CCM. The GDL was placed on the anode and cathode side of the CCM to form the MEAs. After assembling the single cell, the MEAs were fully hydrated by feeding fully humidified $\mathrm{N}_{2}$ into the single cell for $2 \mathrm{~h}$. During the operation, fully humidified $\mathrm{H}_{2}$ and air at $70{ }^{\circ} \mathrm{C}$ were fed into the anode and cathode, respectively. The stoichiometry of hydrogen to air was maintained to be 1.5/2.0 and the relative humidity $100 / 100 \%$. After the activation procedure, polarization curves were measured with a commercial test station (Scitech, Korea Inc) at a temperature of $70{ }^{\circ} \mathrm{C}$ and at ambient pressure. Polarization measurements were started at the OCV(Open Circuit Voltage) and the cell was operated in the galvanostatic mode with a scan rate of $36 \mathrm{~mA} / \mathrm{s}$ for each step.

The tensile stress-strain properties of the membranes were tested using a Com-Ten Industries 95T series load frame equipped with a $200 \mathrm{lbf}$ load cell and computerized data acquisition software. Samples of $9 \mathrm{~mm}$ width were deformed at a crosshead speed of $5 \mathrm{~mm} / \mathrm{min}$ with a gauge length of $30 \mathrm{~mm}$.

\section{Results and Discussion}

\subsection{Preparation of the Monomer}

PBP monomer was produced from 2,5-dichloro-p-xylene to subsequent oxidation, chlorination, and Friedel-Crafts acylation reaction with manganese (IV) oxide, thionyl chloride and benzene (Scheme S1). ${ }^{1} \mathrm{H}$ NMR data were in close agreement with our previous work [47]. All the phenyl protons appeared at 7.47-7.88 ppm. The protons in the ortho position $\left(\mathrm{H}_{\mathrm{a}}\right)$ to chlorine atoms appeared at an upfield near 7.48-7.49 ppm because of the mesomeric effect of the chlorine atoms (Figure S1). Additionally, the proton peaks for the ortho, para and meta position of side phenyl rings shifted to the downfield as a result of the electron-withdrawing effect of the carbonyl group and appeared at near $7.83-7.88\left(\mathrm{H}_{\mathrm{b}}\right)$, 7.64-7.69 $\left(\mathrm{H}_{\mathrm{d}}\right)$ and 7.50-7.56 $\left(\mathrm{H}_{\mathrm{c}}\right)$ ppm, respectively. 


\subsection{Preparation of the Sulfonimide Branched PPBP Polymers (SI-Branched PPBP)}

The SI-branched PPBPs were synthesized from PBP monomer and branching agent 1,3,5-trichlorobenzene via a Ni-Zn catalyzed C-C coupling reaction proceeding addition and elimination (Scheme 1). The high molecular weight PPBP polymer was applied to the specific mole ratio of the catalysts $\left(\mathrm{NiBr}_{2}: \mathrm{PPh}_{3}: \mathrm{Zn}=1: 8: 60\right)$ [51-54]. Chlorosulfuric acid was used for the sulfonation of the branched PPBP polymer. Thereafter, all the sulfonic acid groups of the S-PPBP were converted to SI-branched PPBP by a sequential reaction with $\mathrm{SOCl}_{2}$ and sulfamoyl fluoride $\left(\mathrm{FSO}_{2} \mathrm{NH}_{2}\right)$ (Scheme 1).
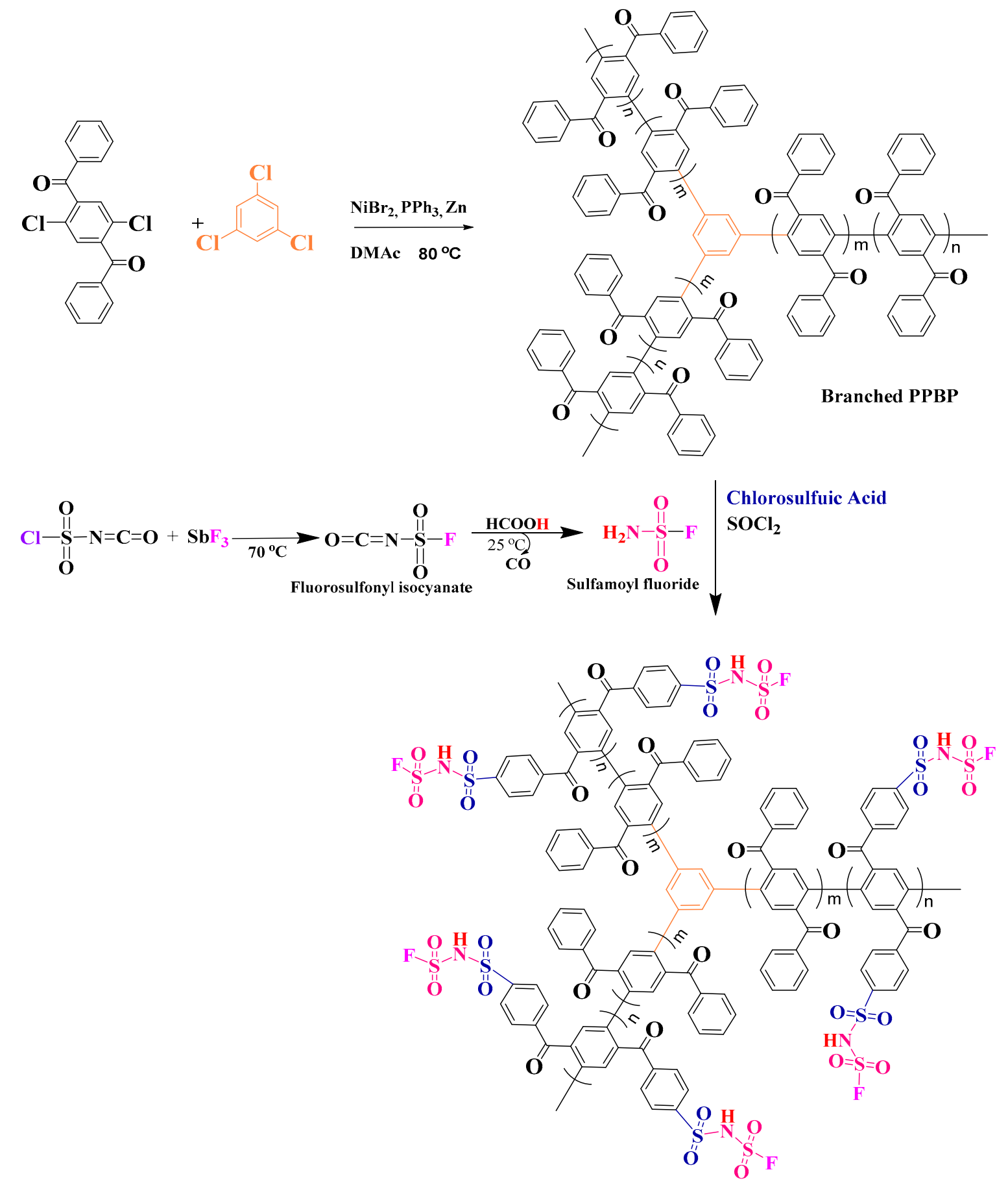

SI-branched PPBP

Scheme 1. Synthesis route to sulfonimide branched poly(phenylenebenzophenone)s (PPBP) polymers (SI-branched PPBP). 
However, ${ }^{1} \mathrm{H}$ NMR, ${ }^{19} \mathrm{~F}$ NMR and FT-IR spectroscopy were used to characterize the chemical structure of the synthesized polymers ( Figure 1; Figure 2, respectively). Figure 1 shows that all phenyl protons for the branched PPBP and S-branched PPBP polymers appear at 6.30-7.79 ppm. Noticeably, the $-\mathrm{SO}_{3} \mathrm{H}$ peaks for branched S-PPBP polymers were found in the upfield at 3.90-4.70 ppm as it conjugated with solvent DMSO and water (Figure $1 \mathrm{~b}$ ). However, after being converted into sulfonimide form, the phenyl protons were observed at $6.80-8.20 \mathrm{ppm}$ slightly shifted downfield by the sulfonimide groups (Figure 1c). The delocalization of the sulfonimide anion is caused by these chemical shifts. Markedly, the -NH- protons appear at 5.20-5.90 ppm as lumpy peaks. On the other hand, the conversion of sulfonimide groups confirms the disappearance of the protons of sulfonic acid groups at 3.90-4.70 ppm. Furthermore, in the ${ }^{19} \mathrm{~F}-\mathrm{NMR}$, a notable peak of the fluorine atom in SI-branched PPBP polymer shows at $-139.44 \mathrm{ppm}$ and successfully attached to the sulfonimide groups on the S-PPBP polymer (Figure 1d).

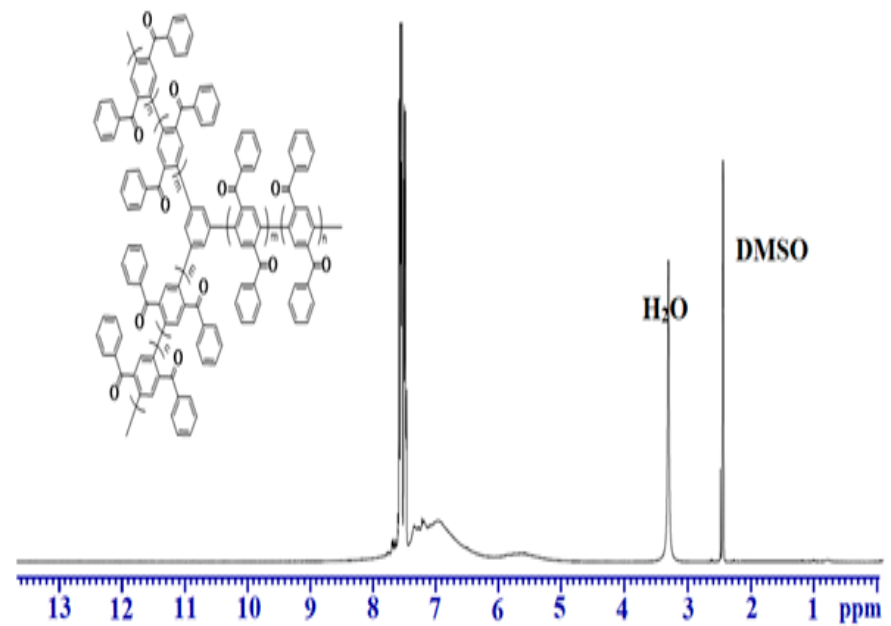

(a)

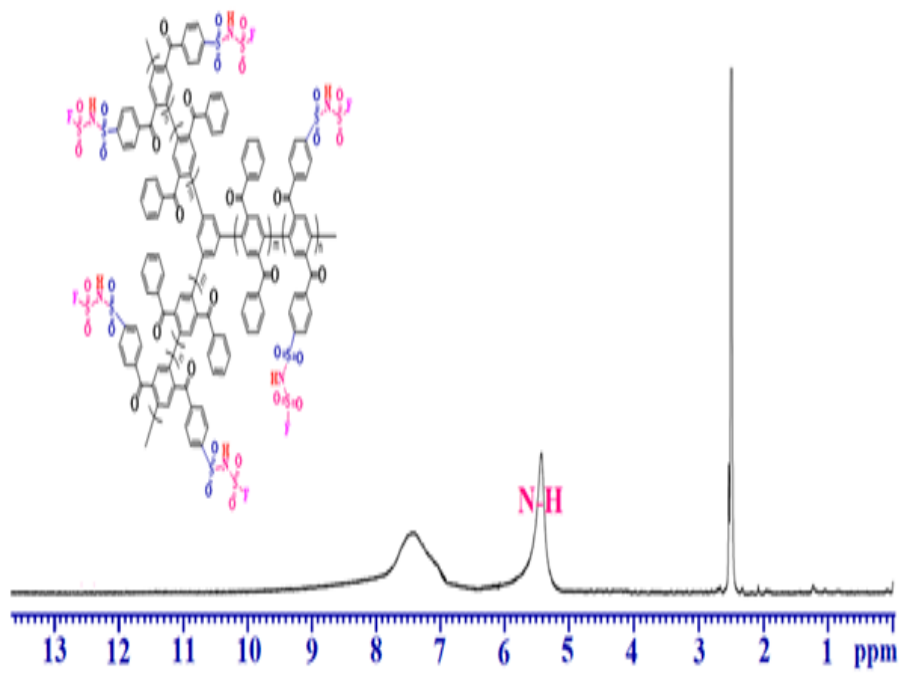

(c)

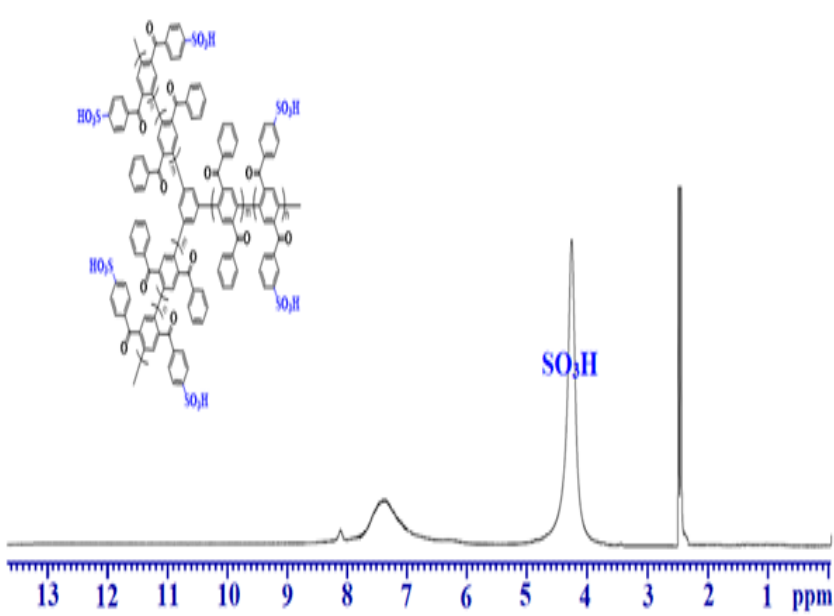

(b)

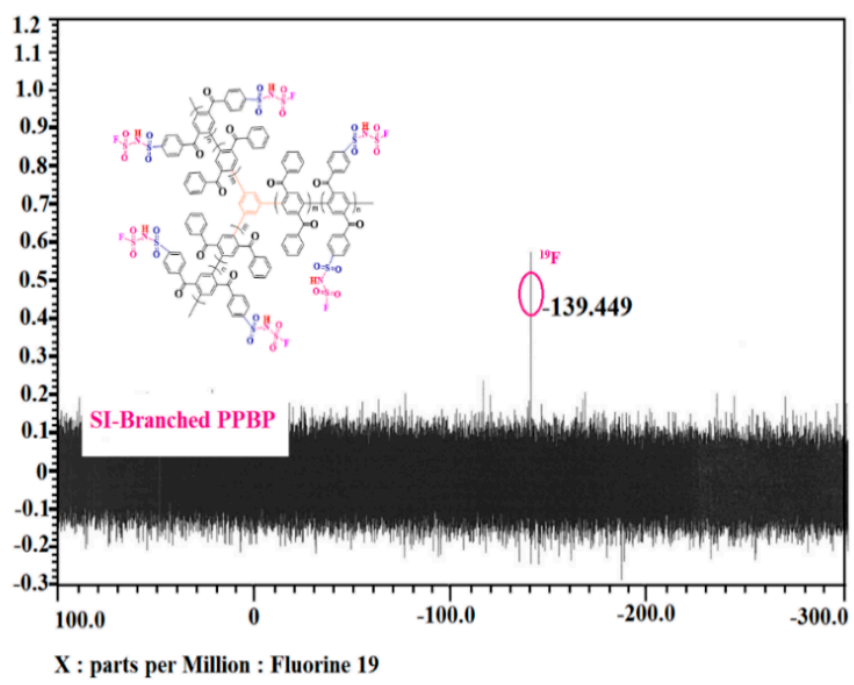

(d)

Figure 1. ${ }^{1} \mathrm{H}-\mathrm{NMR}$ of (a) branched PPBP, (b) S-branched PPBP and (c) SI-branched PPBP polymers. (d) ${ }^{19}$ F-NMR of the SI-branched PPBP polymers. 


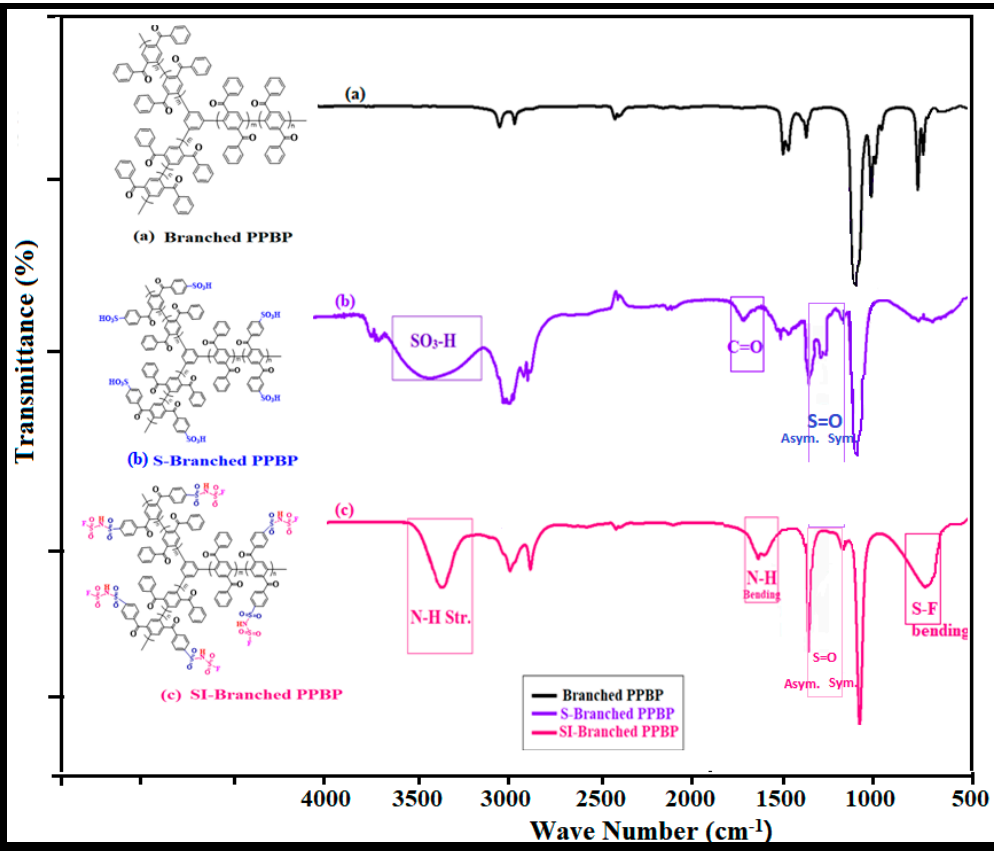

Figure 2. FT-IR for branched PPBP, S-branched PPBP and SI-branched PPBP polymers.

Figure 2 shows the FT-IR spectra for the synthesized polymers. The broad stretching frequencies ranging from $2800-3650 \mathrm{~cm}^{-1}$ correspond to the $-\mathrm{OH}$ groups of the S-branched PPBP polymers. The asymmetric and symmetric stretching vibration of sulfone units $(\mathrm{S}=\mathrm{O})$ in sulfonate groups appear at 1420 and $1140 \mathrm{~cm}^{-1}$ and the stretching frequencies of carbonate groups $(\mathrm{C}=\mathrm{O})$ appear at $1670 \mathrm{~cm}^{-1}$. However, the sharp characteristic peaks for $\mathrm{N}-\mathrm{H}$ stretching found at $3500 \mathrm{~cm}^{-1}$ and $\mathrm{N}-\mathrm{H}$ bending were overlapped with a $\mathrm{C}=\mathrm{O}$ stretching vibration at $1610 \mathrm{~cm}^{-1}$ for the SI-branched PPBP polymers. Additionally, the frequencies at $650 \mathrm{~cm}^{-1}$ for S-F stretching, with some contribution from S-N-S angle bending, confirms that the sulfonimides were incorporated into the sulfuric acid groups.

\subsection{IEC, Water Uptake and Dimensional Stability of Membranes}

Proton conductivity depends on ion exchange capacity (IEC) values i.e., the content of the sulfonimide functionalized groups of the membranes. The synthesized SIbranched PPBP membranes show a gradual increase in water uptake as IEC values increase. (Figure 3). The measured water uptake for the SI-branched PPBP membranes ranged from $25.3 \%$ to $66.8 \%$, whereas Nafion $117^{\circledR}$ typically shows $32.17 \%$ water uptake.

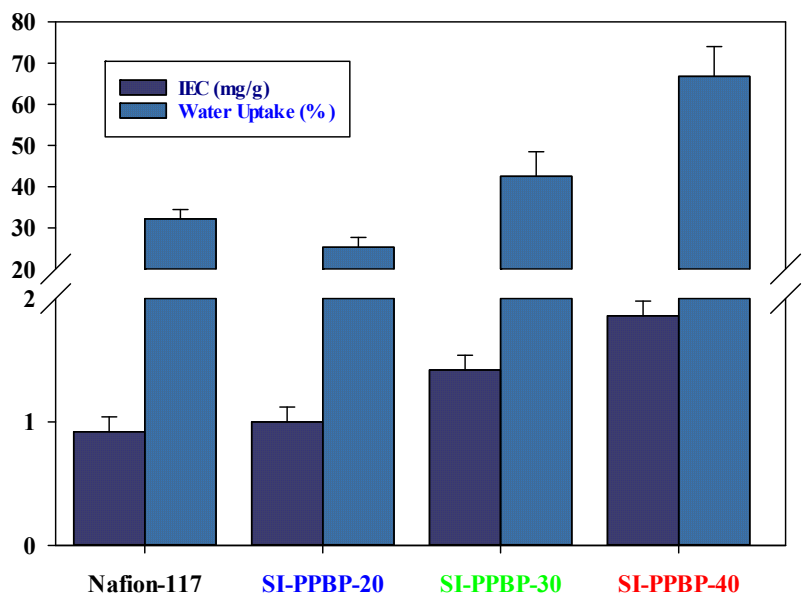

Figure 3. Ion exchange capacity (IEC) and water uptake (WU) for the SI-branched PPBP polymers. 
Dimensional stabilities (through-plane $(\Delta t)$ and in-plane $(\Delta \mathrm{l})$ changes) are important factors for membrane stacks which are usually affected by temperature and humidity. The SI-branched PPBP membranes exhibited lower $\Delta \mathrm{t}(3.1 \%, 4.7 \%$, and $7.6 \%)$ and $\Delta \mathrm{l}(5.2 \%, 6.3 \%$, and $10.8 \%$ ) values compared to Nafion $117^{\circledR}(\Delta t=32.21$ and $\Delta \mathrm{l}=14.10 \%)$ (Table 1$)$. The wholly aromatic and branched polymer backbones of the SI-branched PPBP membranes are the main cause of this lower-dimensional change.

Table 1. Properties of membranes.

\begin{tabular}{|c|c|c|c|c|c|c|c|c|c|c|}
\hline \multirow[t]{2}{*}{ Polymers } & \multirow{2}{*}{$\begin{array}{c}\text { Viscosity } \\
\eta_{\text {int }}(\mathrm{dl} / \mathrm{g})\end{array}$} & \multirow{2}{*}{$\underset{(\mathrm{meq} / \mathrm{g})}{\mathrm{IEC}}$} & \multirow{2}{*}{ 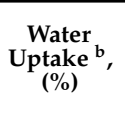 } & \multicolumn{2}{|c|}{$\begin{array}{c}\text { Dimensional } \\
\text { Changes }\end{array}$} & \multirow{2}{*}{$\begin{array}{c}\text { Hydration } \\
\text { Number, } \\
\text { Per Sulfonimide } \\
\text { Group }{ }^{c}, \lambda\end{array}$} & \multicolumn{2}{|c|}{ Membrane Properties } & \multirow{2}{*}{$\begin{array}{l}\text { Conductivity } \\
\text { Measurement }^{\mathrm{d}} \text {, } \\
\sigma \\
(\mathrm{mS} / \mathrm{cm})\end{array}$} & \multirow{2}{*}{ 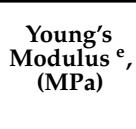 } \\
\hline & & & & $\Delta \mathrm{t}(\%)$ & $\Delta \mathrm{l}(\%)$ & & $\begin{array}{c}\text { Shape, } \\
\text { cm }\end{array}$ & $\begin{array}{l}\text { Thickness, } \\
\text { L } \mu \mathrm{m}\end{array}$ & & \\
\hline $\begin{array}{l}\text { SI-branched } \\
\text { PPBP-20 }\end{array}$ & 0.73 & 1.00 & 25.3 & 3.1 & 5.2 & 14.0 & $2 \times 3$ & 75 & 75.9 & 1030 \\
\hline $\begin{array}{l}\text { SI-branched } \\
\text { PPBP-30 }\end{array}$ & 0.82 & 1.42 & 42.5 & 4.7 & 6.3 & 16.59 & $2 \times 3$ & 75 & 83.1 & 1065 \\
\hline $\begin{array}{l}\text { SI-branched } \\
\text { PPBP-40 }\end{array}$ & 0.93 & 1.86 & 66.8 & 7.6 & 10.8 & 19.95 & $2 \times 3$ & 75 & 121.887 & 1120 \\
\hline Nafion- $117^{\circledR}$ & - & 0.91 & 32.17 & 31.21 & 14.10 & 19.6 & $2 \times 3$ & 175 & 84.74 & 165.16 \\
\hline
\end{tabular}

a Data obtained in DMSO at $30{ }^{\circ} \mathrm{C} .{ }^{b}$ Water uptake at $80{ }^{\circ} \mathrm{C} .{ }^{\mathrm{c}}$ Dimensional changes at $80{ }^{\circ} \mathrm{C} .{ }^{\mathrm{d}}$ Proton conductivity $90 \% \mathrm{RH}$ and $90{ }^{\circ} \mathrm{C}$.

e Dry condition.

\subsection{Proton Conductivity of the SI-Branched PPBP Membranes}

Measurements of the proton conductivity of the synthesized membranes were carried out at a range of temperatures $\left(30-90{ }^{\circ} \mathrm{C}\right)$ and humidities $(30-90 \% \mathrm{RH})$. In Figure $4 \mathrm{a}$, the proton conductivities are demonstrated at a specified temperature $\left(\mathrm{RT}=90^{\circ} \mathrm{C}\right)$ with different relative humidities (30-90\% RH). A gradual increase in proton conductivity for the SI-branched PPBP membranes was observed throughout the applied humidity range. Noticeably, SI-branched PPBP-40 membranes exhibited higher conductivity than Nafion $117^{\circledR}$ over $80 \%$ relative humidity. The delocalization of the sulfonimide groups within the polymer network retains and facilitates the high proton transfer capability of the SIbranched PPBP membranes. Additionally, Figure $4 \mathrm{~b}$ displays the proton conductivity of the SI-branched PPBP membranes at gradually increasing temperatures $\left(30-90^{\circ} \mathrm{C}\right)$ with a fixed relative humidity $(\mathrm{RH}=90 \%)$. Markedly, the SI-branched PPBP-40 membrane shows higher proton conductivity $(121.88 \mathrm{mS} / \mathrm{cm})$ than Nafion $117^{\circledR}(84.74 \mathrm{mS} / \mathrm{cm})$ at the same condition. Moreover, synthesized SI-branched PPBP-20 and 30 membranes also exhibited almost analogous conductivities $\left(75.9,83.9 \mathrm{mS} / \mathrm{cm}\right.$ respectively) to Nafion $117^{\circledR}$ at the $90^{\circ} \mathrm{C}$ and $90 \% \mathrm{RH}$ condition. The higher super acidity and the greater number of sulfonimide groups that formed continuous ionic channels in the SI-branched PPBP-40 membranes typically accounted for the higher proton conductivity.

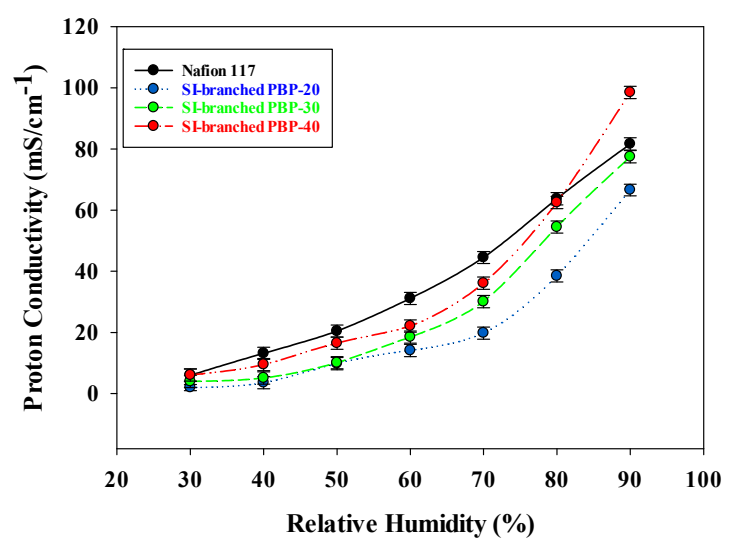

(a)

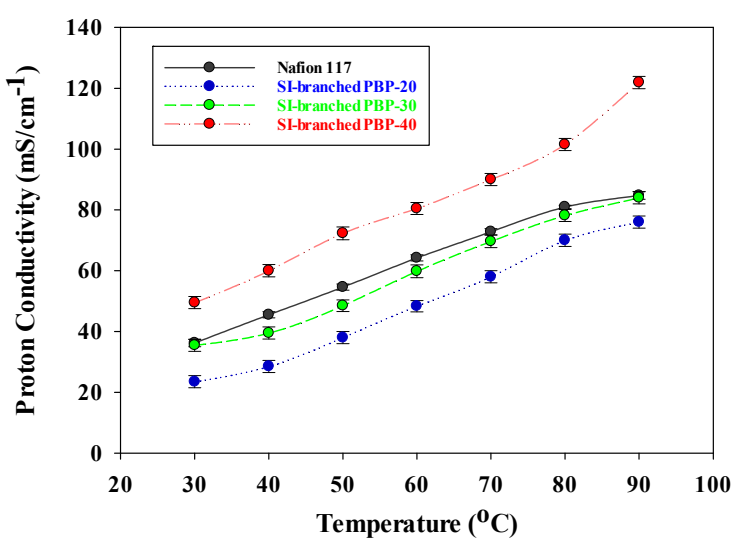

(b)

Figure 4. Proton conductivity for the SI-branched PPBP polymer membranes in (a) different relative humidity at $90{ }^{\circ} \mathrm{C}(\mathbf{b})$ different temperatures at $90 \% \mathrm{RH}$. 


\subsection{Thermo-Oxidative Stability of Membranes}

Figure 5 shows the thermal degradation curves for the thermal resistance of the membranes in an air atmosphere. The branched PPBP polymer exhibited weight loss at 350 ${ }^{\circ} \mathrm{C}$ for the polymer backbone degradation. In the case of SI-branched PPBP membranes, the degradation showed two-step weight loss at $225-320^{\circ} \mathrm{C}$ and $350-450{ }^{\circ} \mathrm{C}$, which corresponded to the decomposition of sulfonimide acid groups and degradation of the polymer main chains, respectively. Therefore, the exhibited thermal stability of the SI-branched PPBP copolymers is suitable for fuel cell applications.

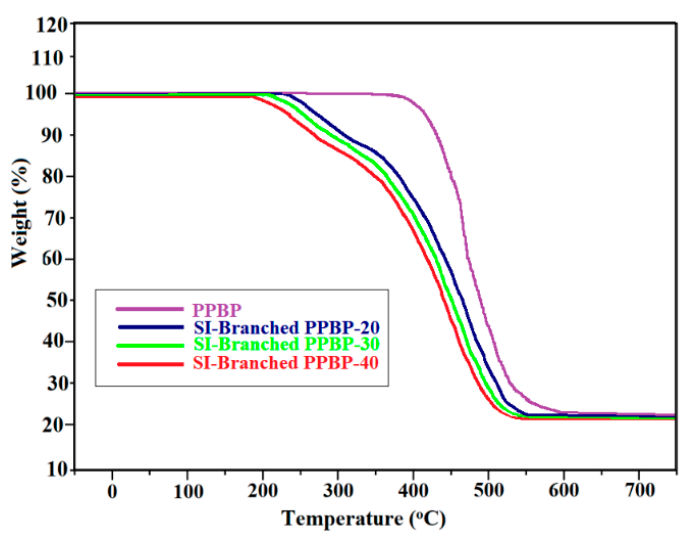

Figure 5. Thermogravimetric analysis (TGA) of SI-branched PPBP polymers.

\subsection{Chemical Stability of Membranes}

Chemical stability was measured by free radical degradation of the SI-branched PPBP membranes and studied using Fenton's reagent. Figure 6 shows that the SI-branched PPBP membranes have superior chemical stability compared to SPAES- 40 membranes against free radical attack. The excellent chemical stability of the SI-branched PPBP membranes is due to a lower susceptibility of their C-C bonded polymer backbones to free radical attack than membranes containing ether linkages (SPAES-40). Moreover, the fluorine atoms of the sulfonimide groups resist free radical attacks. Therefore, the SI-branched PPBP membranes can provide long-term stability in fuel cell applications.

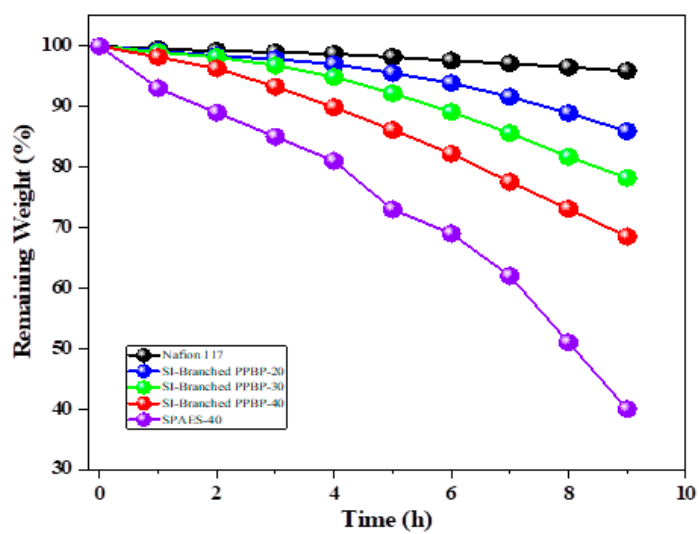

Figure 6. Fenton's reagent $\left(3 \mathrm{ppm} \mathrm{Fe}^{2+}\right)$ test for the SI-branched PPBP polymer membranes.

\subsection{Morphology of the Membranes}

Figure 7 shows the bare eye views for branched $\operatorname{PPBP~}(\mathrm{a}, \mathrm{b}$ and $\mathrm{c})$ and morphological images for the SI-branched PPBP polymer membranes ( $\mathrm{e}, \mathrm{f}$ and $\mathrm{g}$ ) where the bright and dark colored portions in e, $\mathrm{f}$ and $\mathrm{g}$ represent the hydrophobic and hydrophilic domain, respectively [55]. The location of the sulfonimide groups in the pendant phenyl rings provides a clear phase-separation between hydrophobic and hydrophilic domains for the SI-branched PPBP membranes. In the AFM images, the SI-branched PPBP-40 membranes 
exhibit a great number of black dark spots as an adequate number of ion-conducting sulfonimide groups made a continuous channel for proton passage throughout the polymer network. On the contrary, SI-branched PPBP-20 membranes exhibited very few dark spots, indicating interrupted ionic channels due to the presence of a smaller quantity of sulfonimide groups.

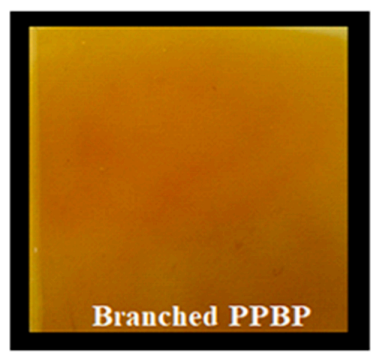

(a)

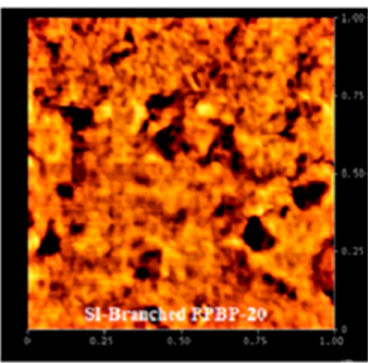

(e)

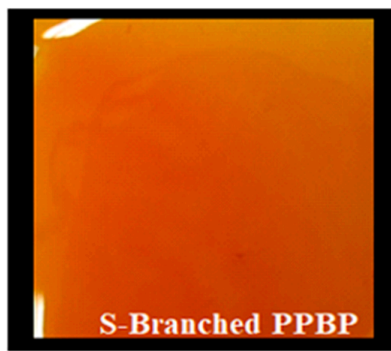

(b)

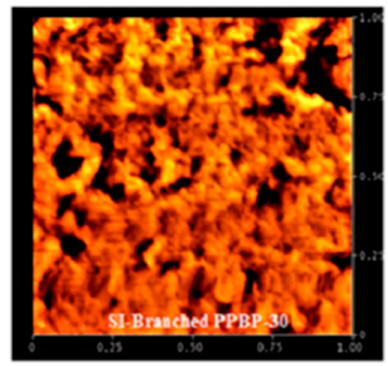

(f)

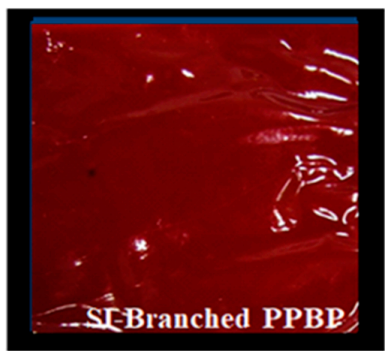

(c)

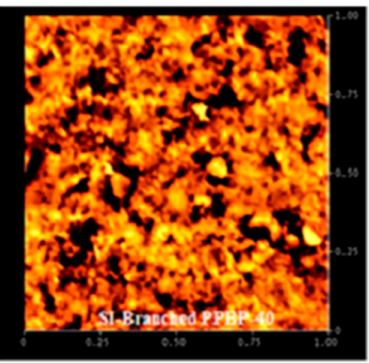

(g)

Figure 7. Images for (a) branched PPBP, (b) S-branched PPBP, and (c) SI-branched PPBP polymers and atomic force microscopy images for (e) SI-branched PPBP-20, (f) SI-branched PPBP-30, and (g) SI-branched PPBP-40 polymers.

\subsection{Cell Performance of the SI-Branched PPBP Membranes}

The single-cell performance of the SI-branched PPBP membranes is measured in terms of cell voltage and power density (Figure 8). Markedly, the SI-branched PPBP-40 membranes have a power density from 0.49 to $0.63 \mathrm{~W} / \mathrm{cm}^{2}$ as compared to Nafion $117^{\circledR}$ $0.62 \mathrm{~W} / \mathrm{cm}^{2}$. However, synthesized SI-branched PPBP-20 and 30 membranes also showed comparable maximum power densities of 0.49 and $0.56 \mathrm{~W} / \mathrm{cm}^{2}$, respectively.

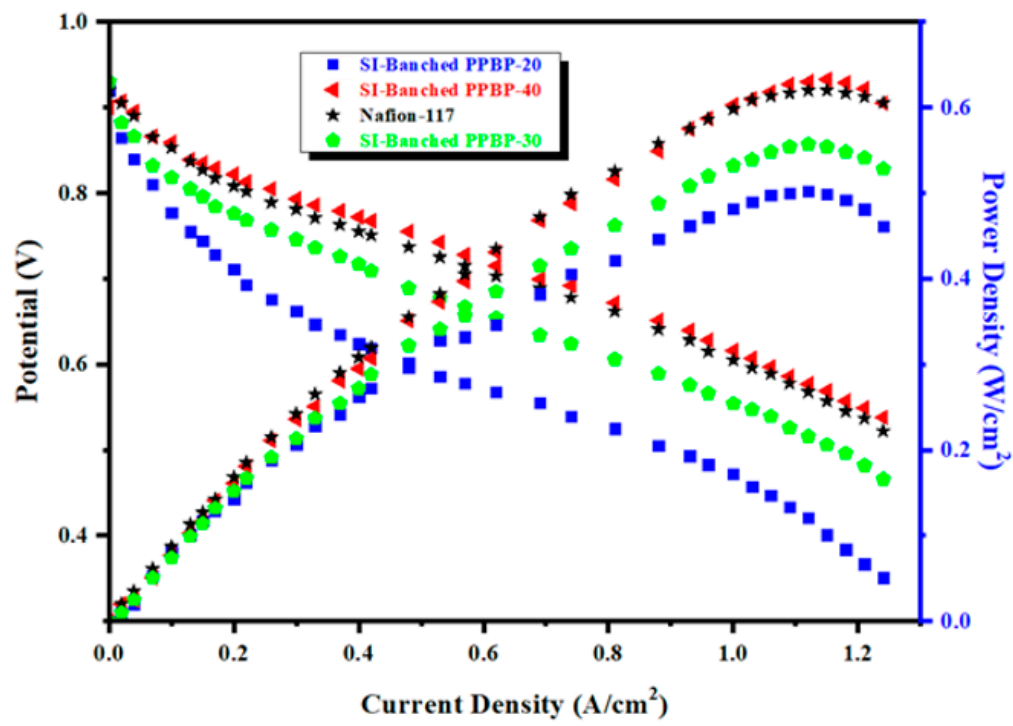

Figure 8. Cell performance for the SI-branched PPBP polymer membranes. 


\section{Conclusions}

A series of branched sulfonimide-based poly(phenylenebenzophenone)s membranes (SI-branched PPBP) have been successfully synthesized from 1,4-dichloro-2,5diphenylenebenzophenone (PBP) monomers using 1,3,5-trichlorobenzene as a branching agent $(0.1 \%)$ by Ni-Zn catalyzed $\mathrm{C}-\mathrm{C}$ coupling polymerization. The nickel-zinc catalyzed $\mathrm{C}-\mathrm{C}$ coupled polymer backbones with branching agent improved the thermal and chemical properties of the synthesized SI-branched PPBP membranes. Moreover, sulfonimide groups had significantly improved thermal properties because of $\mathrm{C}-\mathrm{C}$ bonded polymer backbones and improved chemical stability because of a low susceptibility to free radical attack. The SI-branched PPBP-40 membranes showed high proton conductivity of $121.88 \mathrm{mS} / \mathrm{cm}$ at $90{ }^{\circ} \mathrm{C} / 90 \% \mathrm{RH}$, which is almost $43 \%$ higher than Nafion $117^{\circledR}(84.74 \mathrm{mS} / \mathrm{cm})$. The excellent water retention ability of the SI-branched PPBP membranes improved electrochemical performances in single-cell PEMFCs under $70{ }^{\circ} \mathrm{C} / 100 \% \mathrm{RH}$, reaching a peak power density value of $0.631 \mathrm{~W} / \mathrm{cm}^{2} @ 70{ }^{\circ} \mathrm{C} / 100 \% \mathrm{RH}$. The thermogravimetric analysis and Fenton's test results also demonstrated the excellent thermal and chemical properties of the synthesized SI-branched PPBP copolymers. Additionally, the pendant sulfonimide groups allowed for a microphase separation between the hydrophilic and hydrophobic segments which enhanced proton conductivity. Therefore, the synthesized SI-branched PPBP membranes could be inexpensive electrolyte membranes for PEMFCs.

Supplementary Materials: The following are available online at https: / / www.mdpi.com/2077-037 5/11/3/168/s1, Scheme S1: Synthesis route for PBP monomer, Figure S1: ${ }^{1} \mathrm{H}$ NMR of PBP monomer.

Author Contributions: Conceptualization, W.K., and H.J.; methodology, S.C.S.; software, S.C.S. and L.J.; validation, S.Y., T.R. and L.J.; formal analysis, T.R.; investigation, S.Y., W.Z., and T.R.; resources, W.K.; data curation, L.J. writing-original draft preparation, S.C.S.; writing-review and editing, H.J.; visualization, S.Y.; supervision, H.J.; project administration, W.K. All authors have read and agreed to the published version of the manuscript.

Funding: This research received no external funding.

Institutional Review Board Statement: Not applicable.

Informed Consent Statement: Not applicable.

Data Availability Statement: Data sharing is not applicable to this article.

Acknowledgments: This work was supported by Konkuk University, 2020.

Conflicts of Interest: The authors declare no conflict of interest.

\section{References}

1. Hensley, J.E.; Way, J.D. Synthesis and Characterization of Perfluorinated Carboxylate/ Sulfonate Ionomer Membranes for Separation and Solid Electrolyte Applications. Chem. Mater. 2007, 19, 4576-4584. [CrossRef]

2. Li, N.; Shin, D.W.; Hwang, D.S.; Lee, Y.M.; Guiver, M.D. Polymer Electrolyte Membranes Derived from New Sulfone Monomers with Pendent Sulfonic Acid Groups. Macromolecules 2010, 43, 9810-9820. [CrossRef]

3. Li, W.; Manthiram, A.; Guiver, M.D. Acid-Base Blend Membranes Consisting of Sulfonated Poly(Ether Ether Ketone) and 5-Amino-Benzotriazole Tethered Polysulfone for DMFC. J. Memb. Sci. 2010, 362, 289-297. [CrossRef]

4. Matsumura, S.; Hlil, A.R.; Du, N.; Lepiller, C.; Gaudet, J.; Guay, D.; Shi, Z.; Holdcroft, S.; Hay, A.S. Ionomers for Proton Exchange Membrane Fuel Cells with Sulfonic Acid Groups on the End-Groups: Novel Branched Poly(Ether-Ketone)s with 3,6-Ditrityl-9H-Carbazole End-Groups. J. Polym. Sci. Part A Polym. Chem. 2008, 46, 3860-3868. [CrossRef]

5. Haile, S.M.; Boysen, D.A.; Chisholm, C.R.I.; Merie, R.B. Solid Acids as Fuel Cell Electrolytes. Nature 2001, 410, 910-913. [CrossRef]

6. Rozière, J.; Jones, D.J. Non-Fluorinated Polymer Materials for Proton Exchange Membrane Fuel Cells. Annu. Rev. Mater. Res. 2003, 33, 503-555. [CrossRef]

7. Hickner, M.A.; Ghassemi, H.; Kim, Y.S.; Einsla, B.R.; McGrath, J.E. Alternative Polymer Systems for Proton Exchange Membranes (PEMs). Chem. Rev. 2004, 104, 4587-4612. [CrossRef] [PubMed]

8. Lim, Y.; Lee, S.; Jang, H.; Hossain, M.A.; Gwak, G.; Ju, H.; Kim, D.; Kim, W. Sulfonated Poly(Ether Sulfone) Electrolytes Structured with Mesonaphthobifluorene Graphene Moiety for PEMFC. Int. J. Hydrog. Energy 2014, 39, 1532-1538. [CrossRef]

9. Seo, D.W.; Lim, Y.D.; Lee, S.H.; Jeong, Y.G.; Hong, T.W.; Kim, W.G. Preparation and Characterization of Sulfonated AminePoly(Ether Sulfone)s for Proton Exchange Membrane Fuel Cell. Int. J. Hydrog. Energy 2010, 35, 13088-13095. [CrossRef] 
10. Kim, D.S.; Robertson, G.P.; Kim, Y.S.; Guiver, M.D. Copoly(Arylene Ether)s Containing Pendant Sulfonic Acid Groups as Proton Exchange Membranes ${ }^{\dagger}+$ NRCC Publication No. 50899. Macromolecules 2009, 42, 957-963. [CrossRef]

11. Baijun, L.; Gilles, P.R.; Dae-Sik, K.; Michael, D.G.; Wei, H.; Zhenhua, J. Aromatic Poly(ether ketone)s with Pendant Sulfonic Acid Phenyl Groups Prepared by a Mild Sulfonation Method for Proton Exchange Membranes. Macromolecules 2007, 40, 1934-1944. [CrossRef]

12. Park, C.H.; Lee, C.H.; Guiver, M.D.; Lee, Y.M. Sulfonated Hydrocarbon Membranes for Medium-Temperature and Low-Humidity Proton Exchange Membrane Fuel Cells (PEMFCs). Prog. Polym. Sci. 2011, 36, 1443-1498. [CrossRef]

13. Kim, D.J.; Jo, M.J.; Nam, S.Y. A Review of Polymer-Nanocomposite Electrolyte Membranes for Fuel Cell Application. J. Ind. Eng. Chem. 2015, 21, 36-52. [CrossRef]

14. Branco, C.M.; Sharma, S.; de Camargo Forte, M.M.; Steinberger-Wilckens, R. New Approaches towards Novel Composite and Multilayer Membranes for Intermediate Temperature-Polymer Electrolyte Fuel Cells and Direct Methanol Fuel Cells. J. Power Sources 2016, 316, 139-159. [CrossRef]

15. Cho, C.G.; Kim, Y.S.; Yu, X.; Hill, M.; McGrath, J.E. Synthesis and Characterization of Poly(Arylene Ether Sulfone) Copolymers with Sulfonimide Side Groups for a Proton-Exchange Membrane. J. Polym. Sci. Part A Polym. Chem. 2006, 44, 6007-6014. [CrossRef]

16. Harrison, W.L.; Hickner, M.A.; Kim, Y.S.; McGrath, J.E. Poly(Arylene Ether Sulfone) Copolymers and Related Systems from Disulfonated Monomer Building Blocks: Synthesis, Characterization, and Performance-A Topical Review. Fuel Cells 2005, 5, 201-212. [CrossRef]

17. Wang, F.; Hickner, M.; Kim, Y.S.; Zawodzinski, T.A.; McGrath, J.E. Direct Polymerization of Sulfonated Poly(Arylene Ether Sulfone) Random (Statistical) Copolymers: Candidates for New Proton Exchange Membranes. J. Memb. Sci. 2002, 197, $231-242$. [CrossRef]

18. Miyahara, T.; Hayano, T.; Matsuno, S.; Watanabe, M.; Miyatake, K. Sulfonated Polybenzophenone/Poly(Arylene Ether) Block Copolymer Membranes for Fuel Cell Applications. ACS Appl. Mater. Interfaces 2012, 4, 2881-2884. [CrossRef]

19. Baijun, L.; Yu, S.K.; Wei, H.; Gilles, P.R.; Bryan, S.P.; Michael, D.G. Homopolymer-like sulfonated phenyl- and diphenylpoly(arylene ether ketone)s for fuel cell applications. J. Power Sources 2008, 185, 899-903. [CrossRef]

20. Xie, H.; Tao, D.; Xiang, X.; Ou, Y.; Bai, X.; Wang, L. Synthesis and Properties of Highly Branched Star-Shaped Sulfonated Block Poly(Arylene Ether)s as Proton Exchange Membranes. J. Membr. Sci. 2015, 473, 226-236. [CrossRef]

21. Rowlett, J.R.; Chen, Y.; Shaver, A.T.; Lane, O.; Mittelsteadt, C.; Xu, H.; Zhang, M.; Moore, R.B.; Mecham, S.; McGrath, J.E. Multiblock Poly(Arylene Ether Nitrile) Disulfonated Poly(Arylene Ether Sulfone) Copolymers for Proton Exchange Membranes: Part 1 Synthesis and Characterization. Polymer 2013, 54, 6305-6313. [CrossRef]

22. Cataldo, S.; Ernestino, L.; Adele, B.; Giuseppe, B.; Isabella, N. Highly performing and low-cost nanostructured membranes based on Polysulfone and layered doubled hydroxide for high-temperature proton exchange membrane fuel cells. J. Power Sources 2020, 471, 228440. [CrossRef]

23. Yllser, D.; Hu, S.D.; Inci, E. Polybenzimidazole $/ \mathrm{SiO}_{2}$ hybrid membranes for high temperature proton exchange membrane fuel cells. Int. J. Hydrog. Energy 2016, 41, 10044-10052. [CrossRef]

24. Ravi, K.; Mohamed, M.; Keith, S. Sulfonated polyether ether ketone-sulfonated graphene oxide composite membranes for polymer electrolyte fuel cells. RSC Adv. 2014, 4, 617. [CrossRef]

25. Kerres, J.A. Blended and Cross-Linked Ionomer Membranes for Application in Membrane Fuel Cells. Fuel Cells 2005, 5, $230-247$. [CrossRef]

26. Ding, F.C.; Wang, S.J.; Xiao, M.; Meng, Y.Z. Cross-Linked Sulfonated Poly(Phathalazinone Ether Ketone)s for PEM Fuel Cell Application as Proton-Exchange Membrane. J. Power Sources 2007, 164, 488-495. [CrossRef]

27. Lee, K.S.; Jeong, M.H.; Lee, J.P.; Lee, J.S. End-Group Cross-Linked Poly(Arylene Ether) for Proton Exchange Membranes. Macromolecules 2009, 42, 584-590. [CrossRef]

28. Calandra, P.; Turco Liveri, V.; Ruggirello, A.M.; Licciardi, M.; Lombardo, D.; Mandanici, A. Anti-Arrhenian Behaviour of Conductivity in Octanoic Acid-Bis(2-Ethylhexyl)Amine Systems: A Physico-Chemical Study. J. Mater. Chem. C 2015, 3, 3198-3210. [CrossRef]

29. Wang, L.; Li, K.; Zhu, G.; Li, J. Preparation and Properties of Highly Branched Sulfonated Poly(Ether Ether Ketone)s Doped with Antioxidant 1010 as Proton Exchange Membranes. J. Memb. Sci. 2011, 379, 440-448. [CrossRef]

30. Pang, J.; Zhang, H.; Li, X.; Wang, L.; Liu, B.; Jiang, Z. Synthesis and Characterization of Sulfonated Poly(Arylene Ether)s with Sulfoalkyl Pendant Groups for Proton Exchange Membranes. J. Memb. Sci. 2008, 318, 271-279. [CrossRef]

31. Xie, H.; Wang, D.; Tao, D.; Wang, L. Synthesis of Highly Branched Sulfonated Polymers and the Effects of Degree of Branching on Properties of Branched Sulfonated Polymers as Proton Exchange Membranes. J. Power Sources 2014, 262, 328-337. [CrossRef]

32. Li, Y.; Xie, M.; Wang, X.; Chao, D.; Liu, X.; Wang, C. Novel Branched Sulfonated Poly(Ether Ether Ketone)s Membranes for Direct Methanol Fuel Cells. Int. J. Hydrog. Energy 2013, 38, 12051-12059. [CrossRef]

33. Seo, D.W.; Park, H.S.; Choi, S.W.; Jeong, Y.G.; Hong, T.W.; Kim, W.G. Synthesis and Characterization of Branched Sulfonated Poly(Ether Sulfone Ketone) as Proton Exchange Membrane. Polym. J. 2008, 40, 979-985. [CrossRef]

34. Matsumoto, K.; Higashihara, T.; Ueda, M. Star-Shaped Sulfonated Block Copoly(Ether Ketone)s as Proton Exchange Membranes. Macromolecules 2008, 41, 7560-7565. [CrossRef] 
35. Hlil, A.R.; Matsumura, S.; Hay, A.S. Polymers Containing Di(1 H -Benzo[d]Imidazol-2-Yl)Arene Moieties: Polymerization via N-C Coupling Reactions. Macromolecules 2008, 41, 1912-1914. [CrossRef]

36. Kim, T.; Choi, Y.W.; Kim, C.S.; Yang, T.H.; Kim, M.N. Sulfonated Poly(Arylene Ether Sulfone) Membrane Containing Sulfated Zirconia for High-Temperature Operation of PEMFCs. J. Mater. Chem. 2011, 21, 7612-7621. [CrossRef]

37. Park, H.S.; Seo, D.W.; Choi, S.W.; Jeong, Y.G.; Lee, J.H.; Kim, D.I.; Kim, W.G. Preparation and Characterization of Branched and Linear Sulfonated Poly(Ether Ketone Sulfone) Proton Exchange Membranes for Fuel Cell Applications. J. Polym. Sci. Part A Polym. Chem. 2008, 46, 1792-1799. [CrossRef]

38. Wang, L.; Wang, D.; Zhu, G.; Li, J. Synthesis and Properties of Highly Branched Sulfonated Poly(Arylene Ether)s as Proton Exchange Membranes. Eur. Polym. J. 2011, 47, 1985-1993. [CrossRef]

39. Sato, O.; Kasai, T.; Sato, M.; Sakajiri, K.; Tsujii, Y.; Kang, S.; Watanabe, J.; Tokita, M. High-Density Poly(Hexyl Methacrylate) Brushes Offering a Surface for near-Zero Azimuthal Anchoring of Liquid Crystals at Room Temperature. J. Mater. Chem. C 2013, 1, 7992-7995. [CrossRef]

40. Wang, C.; Young Lee, S.; Won Shin, D.; Rae Kang, N.; Lee, Y.M.; Guiver, M.D. Proton-conducting Membranes from Poly(Ether Sulfone)s Grafted with Sulfoalkylamine. J. Memb. Sci. 2013, 427, 443-450. [CrossRef]

41. Zhang, Y.; Wan, Y.; Zhao, C.; Shao, K.; Zhang, G.; Li, H.; Lin, H.; Na, H. Novel Side-Chain-Type Sulfonated Poly(Arylene Ether Ketone) with Pendant Sulfoalkyl Groups for Direct Methanol Fuel Cells. Polymer 2009, 50, 4471-4478. [CrossRef]

42. Kim, D.S.; Robertson, G.P.; Guiver, M.D. Comb-Shaped Poly(Arylene Ether Sulfone)s as Proton Exchange Membranes. Macromolecules 2008, 41, 2126-2134. [CrossRef]

43. Patel, R.; Im, S.J.; Ko, Y.T.; Kim, J.H.; Min, B.R. Preparation and Characterization of Proton Conducting Polysulfone Grafted Poly(Styrene Sulfonic Acid) Polyelectrolyte Membranes. J. Ind. Eng. Chem. 2009, 15, 299-303. [CrossRef]

44. Pang, J.; Zhang, H.; Li, X.; Liu, B.; Jiang, Z. Poly(Arylene Ether)s with Pendant Sulfoalkoxy Groups Prepared by Direct Copolymerization Method for Proton Exchange Membranes. J. Power Sources 2008, 184, 1-8. [CrossRef]

45. Yuan, S.; Guo, X.; Aili, D.; Pan, C.; Li, Q.; Fang, J. Poly(Imide Benzimidazole)s for High-Temperature Polymer Electrolyte Membrane Fuel Cells. J. Memb. Sci. 2014, 454, 351-358. [CrossRef]

46. Sutradhar, S.C.; Jang, H.; Banik, N.; Yoo, J.; Ryu, T.; Yang, H.; Yoon, S.; Kim, W. Synthesis and Characterization of Proton Exchange Poly (Phenylenebenzophenone)s Membranes Grafted with Propane Sulfonic Acid on Pendant Phenyl Groups. Int. J. Hydrog. Energy 2017, 42, 12749-12758. [CrossRef]

47. Sutradhar, S.C.; Rahman, M.M.; Ahmed, F.; Ryu, T.; Yoon, S.; Lee, S.; Kim, J.; Lee, Y.; Jin, Y.; Kim, W. Synthesis of Nickel-Catalyzed Sulfonated Poly (Phenylenebenzophenone)s from Primarily Sulfonated Monomer for Proton Exchange Membranes. Int. J. Hydrog. Energy 2019, 44, 11311-11320. [CrossRef]

48. Sutradhar, S.C.; Rahman, M.M.; Ahmed, F.; Ryu, T.; Yoon, S.; Lee, S.; Kim, J.; Lee, Y.; Jin, Y.; Kim, W. Thermally and Chemically Stable Poly(Phenylenebenzophenone) Membranes for Proton Exchange Membrane Fuel Cells by Ni (0) Catalyst. J. Ind. Eng. Chem. 2019, 76, 233-239. [CrossRef]

49. Sutradhar, S.C.; Rahman, M.M.; Ahmed, F.; Ryu, T.; Yoon, S.; Lee, S.; Jin, Y.; Kim, W. Improved Proton Conductive Membranes from Poly(Phenylenebenzophenone)s with Pendant Sulfonimide Acid Groups for Fuel Cells. J. Power Sources 2019, $442,227233$. [CrossRef]

50. Ahmed, F.; Sutradhar, S.C.; Ryu, T.; Jang, H.; Choi, K.; Yang, H.; Yoon, S.; Rahman, M.M.; Kim, W. Comparative Study of Sulfonated Branched and Linear Poly(Phenylene)s Polymer Electrolyte Membranes for Fuel Cells. Int. J. Hydrog. Energy 2018, 43, 5374-5385. [CrossRef]

51. Ha, Y.H.; Scott, C.E.; Thomas, E.L. Miscible Blends of Poly(Benzoyl Paraphenylene) and Polycarbonate. Polymer 2001, 42, 6463-6472. [CrossRef]

52. Ninivin, C.L.; Balland-Longeau, A.; Demattei, D.; Coutanceau, C.; Lamy, C.; Léger, J.M. Sulfonated Derivatives of Polyparaphenylene as Proton Conducting Membranes for Direct Methanol Fuel Cell Application. J. Appl. Electrochem. 2004, 34, 1159-1170. [CrossRef]

53. Zhang, X.; Sheng, L.; Higashihara, T.; Ueda, M. Polymer Electrolyte Membranes Based on Poly(m-Phenylene)s with Sulfonic Acid via Long Alkyl Side Chains. Polym. Chem. 2013, 4, 1235-1242. [CrossRef]

54. Singh, R.; Hay, A.S. Synthesis and Physical Properties of Soluble, Amorphous Poly(Ether Ketone)s Containing the oDibenzoylbenzene Moiety. Macromolecules 1992, 25, 1017-1024. [CrossRef]

55. Rehahn, M.; Schlüter, A.D.; Wegner, G.; Feast, W.J. Soluble Poly(Para-Phenylene)s. 2. Improved Synthesis of Poly(Para-2,5-Din-Hexylphenylene) via Pd-Catalysed Coupling of 4-Bromo-2,5-Di-n-Hexylbenzeneboronic Acid. Polymer 1989, 30, 1060-1062. [CrossRef] 